\title{
Aplikasi Mobile untuk Usaha Jasa Pengantaran Barang di Dusun Cibeber, Kawasan Industri Jababeka, Bekasi
}

\author{
Tjong Wan Sen \\ Fakultas Komputer, Universitas Presiden, wansen@president.ac.id
}

\begin{abstract}
ABSTRAK
Kegiatan PkM ini ditujukan untuk memberikan alternatif sumber pendapatan bagi warga di Dusun Cibeber yang letaknya berada di pusat Kawawan Industri Jababeka, Cikarang, Bekasi. Dalam kegiatan ini kemajuan teknologi informasi dan komputer, global positioning system, dan internet dimanfaatkan untuk menjadi sebuah aplikasi mobile jasa pengantaran barang yang mudah digunakan dan berbiaya murah serta tidak membutuhkan kualifikasi yang tinggi untuk mengoperasikannya. Aplikasi beserta sistem pendukungnya telah berhasil dirancang, diimplementasikan dan disimulasikan dengan baik. Tahapan berikutnya adalah mengukur kinerjanya secara luas dan nyata di lapangan.
\end{abstract}

Kata-kata kunci: Aplikasi Mobile, Swadaya Masyarakat, Jasa Pengantaran Barang,

Global Positioning System

\section{ABSTRACT}

This Community Services Activity is meant to provide alternative income sources for citizens in Dusun Cibeber which is located in the center of Jababeka Industrial Estate, Cikarang, Bekasi. In this activity advancement of computer and information technology, global positioning system, and telecommunication networks are used to produce a mobile application for delivery services that is easy to use, low cost, and could be operated by common person. The application together with its supporting components has already successfully developed, implemented, and simulated. Next phase would be to measure its performance widely in the real environment.

Keywords: Mobile Application, Citizen Initiative, Delivery Service, Global Positioning System

\section{PENDAHULUAN}

Salah satu masalah utama yang dihadapi oleh warga di Dusun Cibeber, berdasarkan wawancara dengan Ketua RT dan pengamatan langsung di lokasi, adalah banyaknya warga yang tidak bekerja. Dua sebab utamanya adalah (a) siswa putus sekolah karena kesulitan keuangan (walaupun sudah ada Bantuan Operasional Sekolah/BOS); (b) siswa putus sekolah karena lebih suka untuk mulai berwirausaha sejak awal; dan (c) tenaga kerja yang kemampuannya di bawah kriteria perusahaan yang berada di Kawasan Industri Jababeka. Masalah ini perlu segera dicarikan solusi agar tidak menimbulkan masalah yang kompleks dan lebih berat lagi.

Dusun Cibeber berada tepat di dalam Kawasan Industri Jababeka yang dipenuhi oleh bermacam-macam industri, perumahan, dan perkantoran. Lokasi ini memiliki peluang yang tinggi untuk dapat dimanfaatkan menjadi sumber penghasilan. Ditambah lagi dengan adanya lembaga-lembaga pendidikan seperti Universitas Presiden, SMA Presiden, SMP Presiden, dan beberapa sekolah lainnya. Hal ini membuat ada banyak karyawan dan siswa yang bertempat tinggal di kawas tersebut. Pada tahun 2016, telah ada lebih dari 767.000 karyawan yang tinggal di kawasan industri ini. Jumlah tersebut bertambah setiap tahunnya.

Kedua fakta tersebut membuat Dusun Cibeber tepat dijadikan lokasi usaha Jasa Pengantaran Barang. Diperlukan sebuah aplikasi mobile (dilengkapi dengan berbagai sistem pendukungnya) yang dapat digunakan untuk menghubungkan pihak penyedia dan 
pengguna jasa. Jasa tersebut mirip dengan layanan GOFOOD atau jasa pengantaran lainnya yang ditingkatkan dan terbatas hanya untuk kebutuhan kawasan lokal. Di satu sisi layanan ini bisa membuka lapangan kerja dan di sisi yang lain dapat memberikan kemudahan bagi pengguna jasa yang membutuhkan pengantaran barang seperti utamanya makanan, dokumen, dan lainnya. Jika ini berhasil dilakukan maka tidak hanya dampak negatif pengangguran dapat dihindari tetapi juga terbuka peluang alternatif untuk dapat meningkatkan penghasilan warga dengan sederhana, mudah dan murah.

Masalah yang diatasi dalam PKM ini adalah masalah tingginya tingkat warga yang tidak bekerja di Dusun Cibeber. Masalah tersebut diatasi dengan membangun usaha sederhana untuk masyarakat berupa Jasa Pengantaran Barang untuk membuka banyak lapangan kerja yang tidak membutuhkan sumber daya manusia dengan kualifikasi tinggi. Sederhana dan juga tidak membutuhkan biaya yang besar. Tujuan PKM ini adalah membangun sebuah sistem berbasis aplikasi mobile untuk usaha swadaya masyarakat sederhana berupa Jasa Pengantaran Barang untuk mengatasi tingginya tingkat warga yang tidak bekerja di Dusun Cibeber. Beberapa manfaat yang diberikan oleh kegiatan PKM ini adalah (a) membuka peluang kerja bagi mereka yang membutuhkan; (b) memberi kemudahan/kenyamanan bagi pengguna jasa; (3) membuka peluang bagi penjual makanan/minuman, laundry, fotokopi, dan penyedia jasa lainnya untuk meningkatkan pendapatannya tanpa perlu investasi atau biaya tambahan untuk pengantaran.

\section{METODE PELAKSANAAN}

Tahap utama adalah menyediakan aplikasi mobile jasa pengantaran barang sebagai faktor utama. Aplikasi mobile, terutama yang dijalankan pada smartphone, saat ini sudah sangat maju (Charland \& Leroux, 2011). Aplikasi tersebut sudah terbukti dalam banyak kesempatan dapat membantu mempermudah pekerjaan manusia. Hal tersebut dikarenakan dukungan infrastruktur seperti jaringan komunikasi data yang rata-rata sudah baik dan kemampuan alat yang sudah cukup mampu menangani komputasi yang kompleks serta memiliki fitur yang lengkap. Ditambah dengan kemampuan pengembang aplikasi yang semakin kreatif dan inovatif maka kemampuan aplikasi mobile menjadi semakin tinggi dan berbiaya cukup terjangkau.

Salah satu cara cepat untuk mendapatkan aplikasi tersebut diatasi adalah dengan melakukan modifikasi aplikasi instant messenger yang sudah ada pada saat ini. Instant messenger adalah aplikasi yang dapat membantu dua orang pengguna atau lebih untuk berkomunikasi melalui media tulisan/teks (Maina, 2013). Aplikasi ini memanfaatkan jaringan telekomunikasi untuk saling bertukar pesan tulisan. Hal ini tentu sangat berguna karena dapat menghemat waktu dan biaya. Saat ini aplikasi messenger banyak digunakan dalam bisnis dan media untuk berkoordinasi. Contoh aplikasi mobile ini yang banyak digunakan 
saat ini adalah Whatsapp dan LINE. Selain kedua aplikasi tersebut, masih banyak lagi aplikasi baru yang dikembangkan. Messenger merupakan salah satu sarana yang tepat untuk dimanfaatkan dalam layanan pengantaran barang. Informasi seperti lokasi, jumlah barang, dan keterangan-keterangan khusus lainnya dapat dengan mudah disampaikan oleh pengguna layanan kepada penyedia layanan.

Kebutuhan aplikasi untuk mengetahui lokasi geografis pengirim dan penerima dapat diperoleh dengan memanfaatkan Global Positioning Systems (GPS). GPS adalah salah satu teknologi yang dapat membantu seorang pengguna dalam menentukan letak posisi suatu tempat secara geografis (Upadhyaya, Pettygrove, Oliveira \& Jahn, 2019). Teknologi tersebut memudahkan seorang pengguna dalam menentukan arah yang harus diambil dan kemudian menemukan lokasi dari suatu tempat misalnya berdasarkan koordinat-koordinat yang diberikan. Dalam kasus aplikasi mobile, teknologi ini sudah disediakan secara otomatis sebagai fitur di hampir semua smartphone yang ada saat ini. Smartphone tersebut tersedia secara luas di pasaran dengan harga yang sudah sangat terjangkau.

Bantuan Google Map digunakan untuk menampilkan lokasi yang terkait dalam bentuk peta yang umum diketahui oleh masyarakat. Google Map adalah salah satu layanan tidak berbayar yang disediakan oleh perusahaan raksasa Google yang dapat memberikan informasi mengenai rute terpendek dari satu titik ke titik lainnya di dalam kemasan sebuah peta (https://cloud.google.com). Layanan ini juga dapat memberikan rute-rute alternatif jika diperlukan secara otomatis. Versi terbaru layanan ini sekaligus dapat memberikan informasi mengenai kepadatan lalu lintas, jalan satu arah, dan lain sebagainya. Fitur penting terkait dengan aplikasi mobile yang dikembangkan adalah kemampuan untuk menghitung jarak antara satu titik dengan titik tertentu lainnya. Hal ini sangat berguna dalam menentukan biaya transportasi yang diperlukan dalam rangka pengantaran barang. Misalnya jika ingin menggunakan perhitungan rupiah per kilometer. Hal tersebut membuat transaksi menjadi lebih transparan dan adil.

Integrasi keempat hal tersebut ke dalam sebuah aplikasi yang disertai dengan sistem back-end yang memadai untuk digunakan dalam menjalankan kegiatan usaha Jasa Pengiriman Barang yang dimaksud, memanfaatkan metode pengembangan perangkat lunak yang dikenal sebagai Extreme Programming (XP) (Beck, 2000). Kelebihan dari metode ini, dalam kaitannya dengan kegiatan yang dilaksanakan, adalah dapat mencapai tujuan dalam waktu yang singkat (3-4 bulan) dan menimbulkan interaksi yang intens dengan pengguna (dalam hal ini masyarakat). Kelebihan kedua adalah baik untuk memperkenalkan kemajuan teknologi informasi dan proses-proses yang ada di dalamnya kepada masyarakat terutama pemuda.

Dengan tersedianya aplikasi tersebut, kegiatan-kegiatan selanjutnya dapat dimulai. Kegiatan-kegiatan tersebut adalah: 
(a) Sosialisasi yang kemudian diikuti dengan pelatihan terkait sistem yang dikembangkan.

(b) Registrasi pengguna (pihak yang memanfaatkan jasa) dan penyedia jasa (pihak yang memberikan jasa pengantaran) melalui aplikasi.

(c) Verifikasi dan validasi pengguna penyedia jasa oleh sistem sesuai aturan yang disepakati bersama.

(d) Kegiatan interaksi antara pengguna dan penyedia jasa yang telah terverifikasi dan tervalidasi dapat mulai dilakukan.

(e) Proses pencatatan dan dokumentasi dilakukan oleh sistem secara otomatis dan data yang dihasilkan dapat dimanfaatkan untuk kebutuhan evaluasi lebih lanjut.

\section{HASIL DAN PEMBAHASAN}

Hasil pengembangan perangkat lunak berupa aplikasi mobile untuk Usaha Jasa Pengantaran Barang menggunakan Sistem Operasi Android telah berhasil dilakukan. Uji coba dan simulasi pada tingkat laboratorium sudah dilakukan dan menunjukkan hasil yang memuaskan. Aplikasi sudah dapat digunakan untuk penyedia jasa maupun pengguna jasa dengan baik. Sistem pendukung pada sisi server telah siap untuk melayani transaksi data dari pengguna dan penyedia jasa.

Gambar 1 menunjukkan aplikasi mobile Usaha Jasa Pengantaran Barang setelah dipasang pada smartphone. Logo aplikasi ditunjukkan oleh panah merah. Untuk menjalankan aplikasi tersebut pengguna dapat menyentuh logo tersebut. Tampilan pertama setelah aplikasi dijalankan ditunjukkan oleh Gambar 2.

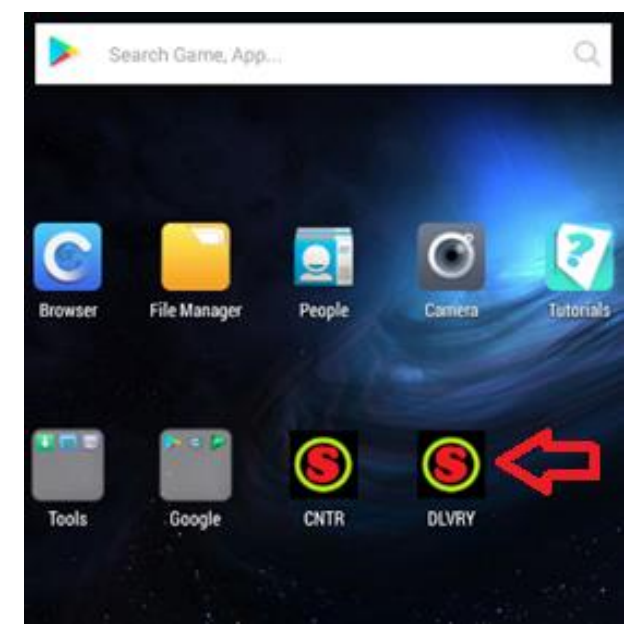

Gambar 1

Aplikasi Usaha Jasa Pengantaran Barang 


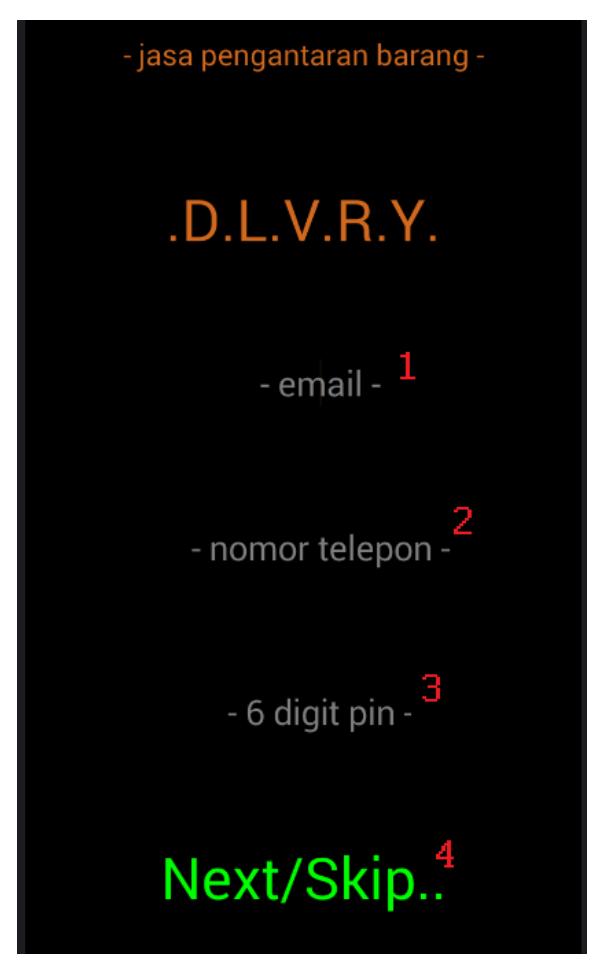

Gambar 2

Halaman Registrasi untuk Pengguna Baru

Gambar 2 menunjukkan halaman registrasi untuk pengguna baru atau belum pernah melakukan registrasi sebelumnya pada smartphone yang sedang digunakan. Tujuan dari fitur ini adalah mengidentifikasi smartphone yang digunakan dan memetakannya pada seorang pengguna. Hal ini ditujukan untuk memudahkan pengguna untuk mulai memanfaatkan layanan tetapi tetap memperhatikan keamanan dengan mencegah pengguna fiktif atau tidak sah.

Beberapa informasi yang perlu diberikan adalah alamat email (ditunjukkan oleh angka 1), nomor telepon (angka 2), dan pin (angka 3). Jika seorang pengguna sudah memberikan data yang lengkap dan benar seperti yang ditunjukkan oleh Gambar 3, maka menyentuh tombol "Next/Skip". Angka 4 akan menyimpan data tersebut ke dalam sistem. Pengguna juga dapat menyentuh tombol tersebut tanpa memberikan data. Jika hal tersebut dilakukan, maka pengguna masih dapat memanfaatkan aplikasi sebagai pengguna yang belum diverifikasi. Untuk pengguna tipe tersebut, beberapa fitur tidak dapat digunakan. Hal ini disediakan utamanya untuk mendukung kesederhanaan dan kemudahan di sisi pengguna melalui fleksibilitas. 


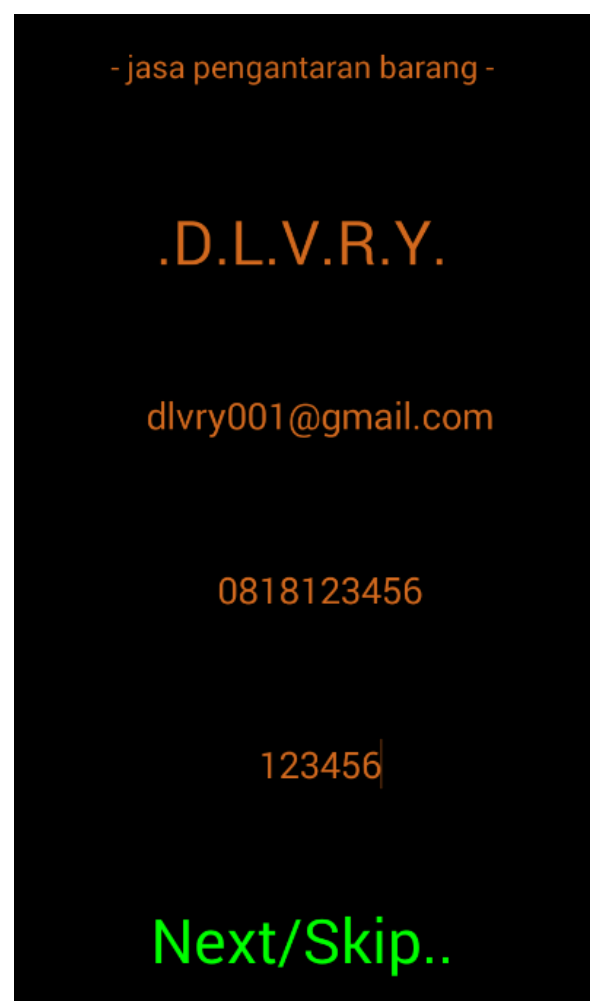

\section{Gambar 3 \\ Contoh Data Rregistrasi yang Benar}

Halaman utama aplikasi ditunjukkan oleh Gambar 4. Halaman ini merupakan titik awal bagi pengguna dan penyedia jasa. Pengguna jasa dapat langsung memberikan informasi sesuai dengan kebutuhannya pada kotak '-ketikkan kebutuhan-' (yang ditunjukkan oleh angka 1) dan menyentuh tombol 'Tawarkan' (angka 2) untuk menyimpannya ke dalam sistem. Begitu penawaran lolos pemeriksaan oleh sistem, penawaran tersebut akan didistribusikan kepada semua penyedia jasa yang sedang online dan memenuhi kriteria. Kriteria-kriteria seperti jarak, reputasi, dan lainnya dapat disesuaikan oleh pengguna dan penyedia jasa secara fleksibel.

Jika pengguna berperan sebagai penyedia jasa, maka pengguna dapat menyentuh tombol 'Lihat tawaran' (angka 3) untuk melihat semua penawaran yang valid untuk pengguna tersebut sebagai penyedia jasa. Tampilan halaman yang menunjukkan hal tersebut ditunjukkan oleh Gambar 6.

Gambar 5 menunjukkan contoh informasi yang diberikan oleh seorang pengguna jasa. Informasi yang diberikan tersebut akan didistribusikan kepada semua penyedia jasa yang sedang aktif pada saat itu (dan memenuhi kriteria jika fitur tersebut diaktifkan). Informasi diberikan dalam bentuk notifikasi pesan dan suara untuk mendapatkan perhatian dari penyedia jasa. Hal ini berguna untuk memastikan setiap tawaran dapat mendapatkan respons yang cepat. 
Academics in Action Journal

Volume 1, Number 1, 2019, 38-49

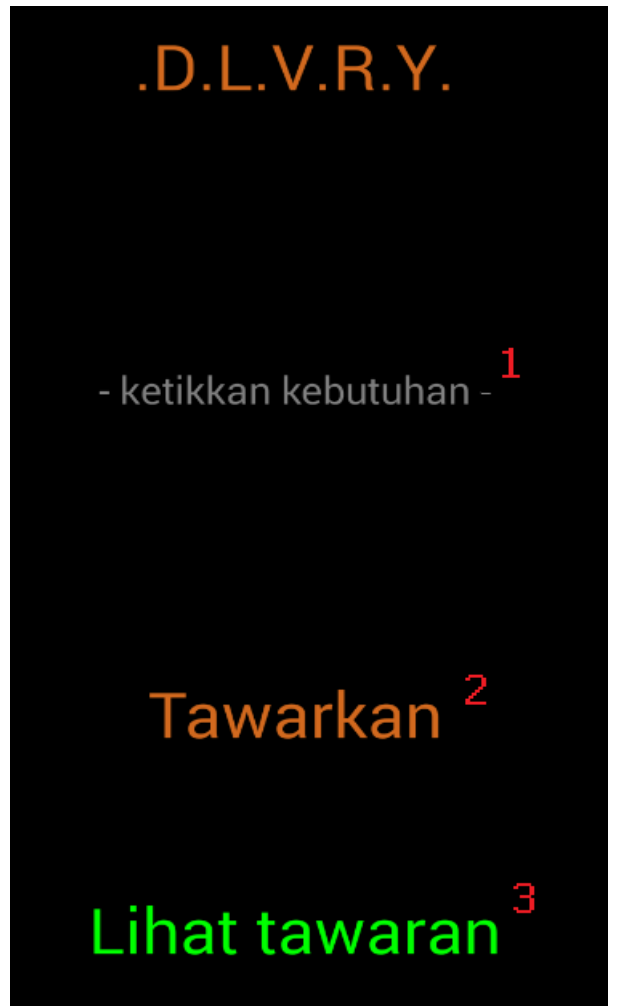

Gambar 4

Halaman Utama Aplikasi

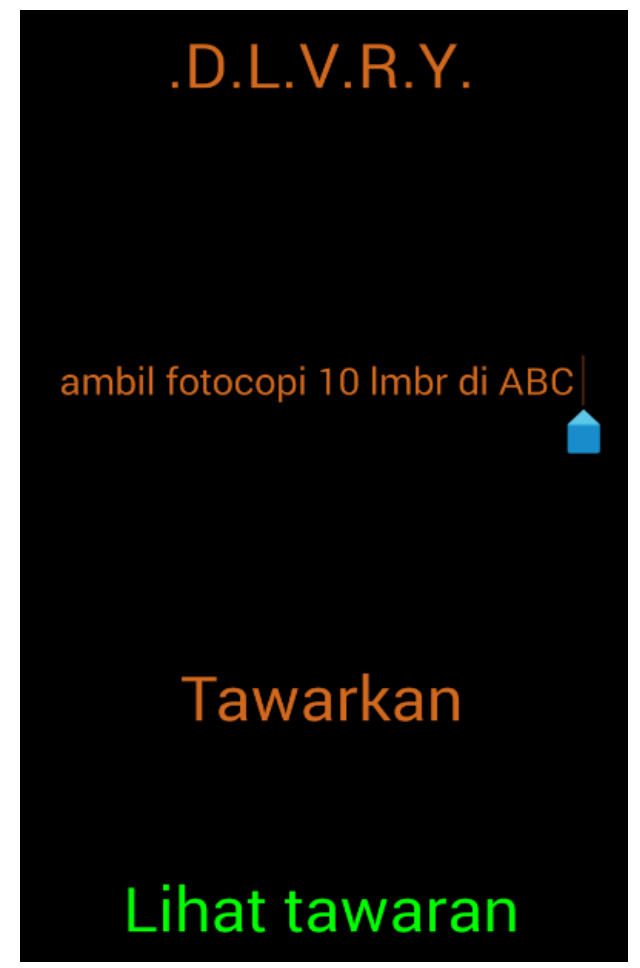

Gambar 5

Contoh Membuat Sebuah Penawaran 


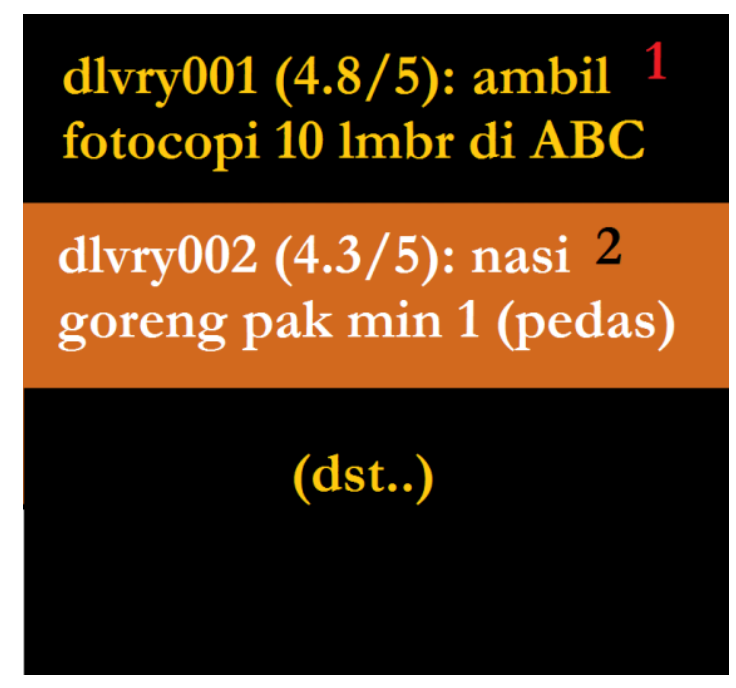

\section{Gambar 6 \\ Daftar Kebutuhan yang Aktif (Sesuai Kriteria)}

Dari sisi penyedia jasa pengantaran, tampilan halaman yang menunjukkan daftar penawaran yang aktif adalah seperti pada Gambar 6. Sama seperti pada sisi pengguna layanan, jika fitur kriteria diaktifkan, maka isi daftar yang tampil akan sesuai dengan kriteria yang dipasang, sehingga masing-masing pengguna dapat menyesuaikannya dengan kebutuhan masing-masing. Tampilan halaman pada Gambar 6 juga akan muncul jika pada halaman utama aplikasi (Gambar 4), pengguna menyentuh tombol 'Lihat tawaran'. Melalui halaman ini penyedia jasa dapat mengetahui detail penawaran lebih jauh dengan cara menyentuh tombol yang bersesuaian. Misalnya untuk mengetahui detail penawaran dari ID 'dlvry001' yang paling atas maka penyedia jasa dapat menyentuh area angka 1 merah dalam gambar (atau dimanapun selama masih di dalam kotak tersebut). Atau dapat menyentuh area angka 2 hitam untuk mendapatkan informasi lebih lanjut mengenai penawaran dari ID 'dlvry002'.

Gambar 7 menunjukkan tampilan halaman detail penawaran. Pada halaman ini penyedia jasa mendapatkan informasi yang lebih lengkap dari penawaran yang dipilihnya. Penyedia jasa juga dapat memanfaatkan Google Map untuk menghitung berapa besar biaya yang diperlukan untuk penawaran tersebut. Untuk melakukan hal tersebut, penyedia jasa dapat menyentuh tombol 'Lihat peta..' seperti yang ditunjukkan oleh angka 1. Aksi tersebut akan membawa penyedia jasa ke halaman rute seperti pada tampilan aplikasi yang ditunjukkan oleh Gambar 8. 


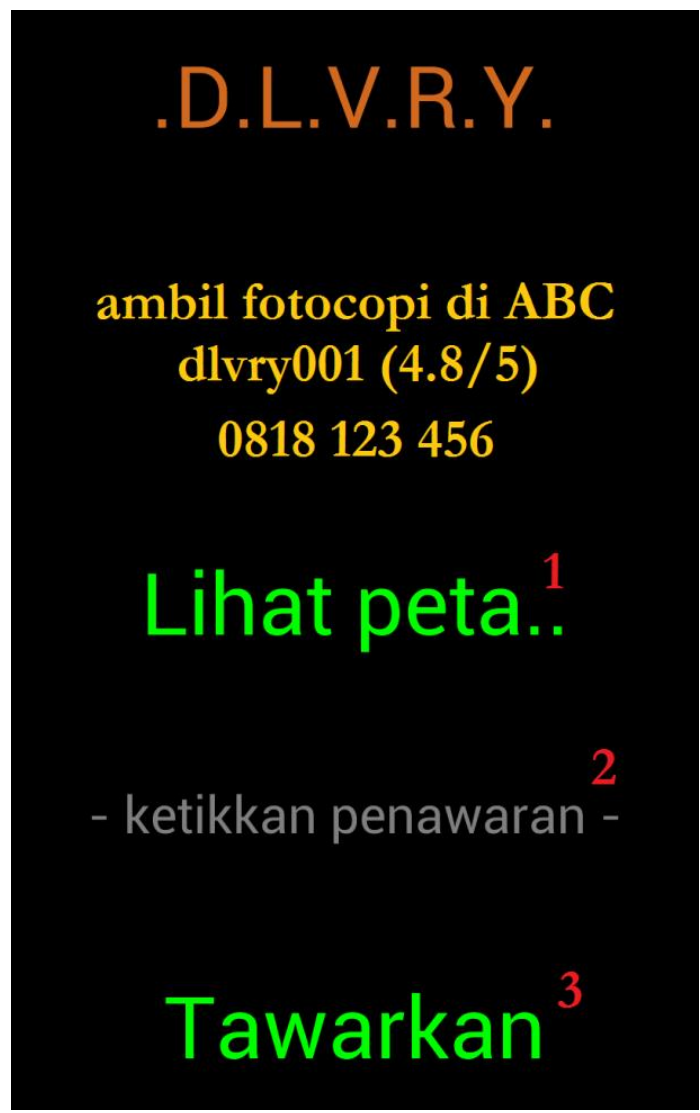

Figure 7

Tampilan Halaman Detail Penawaran

Gambar 8 menunjukkan tampilan halaman terkait posisi penawaran. Tampilan tersebut merupakan hasil dari proses yang dilakukan oleh Google Map berdasarkan koordinat yang dicatat sistem pada saat pengguna membuat penawaran dan posisi penyedia pada saat melihat tawaran. Hasil proses tersebut kemudian diolah lebih lanjut oleh aplikasi dibantu oleh sistem (server). Seperti yang ditunjukkan oleh Gambar 8, informasi terkait waktu yang dibutuhkan dan jarak yang harus ditempuh (ditunjukkan oleh panah merah) dapat diketahui. Informasi tersebut berguna bagi penyedia jasa dalam menentukan biaya yang harus ditawarkan. 


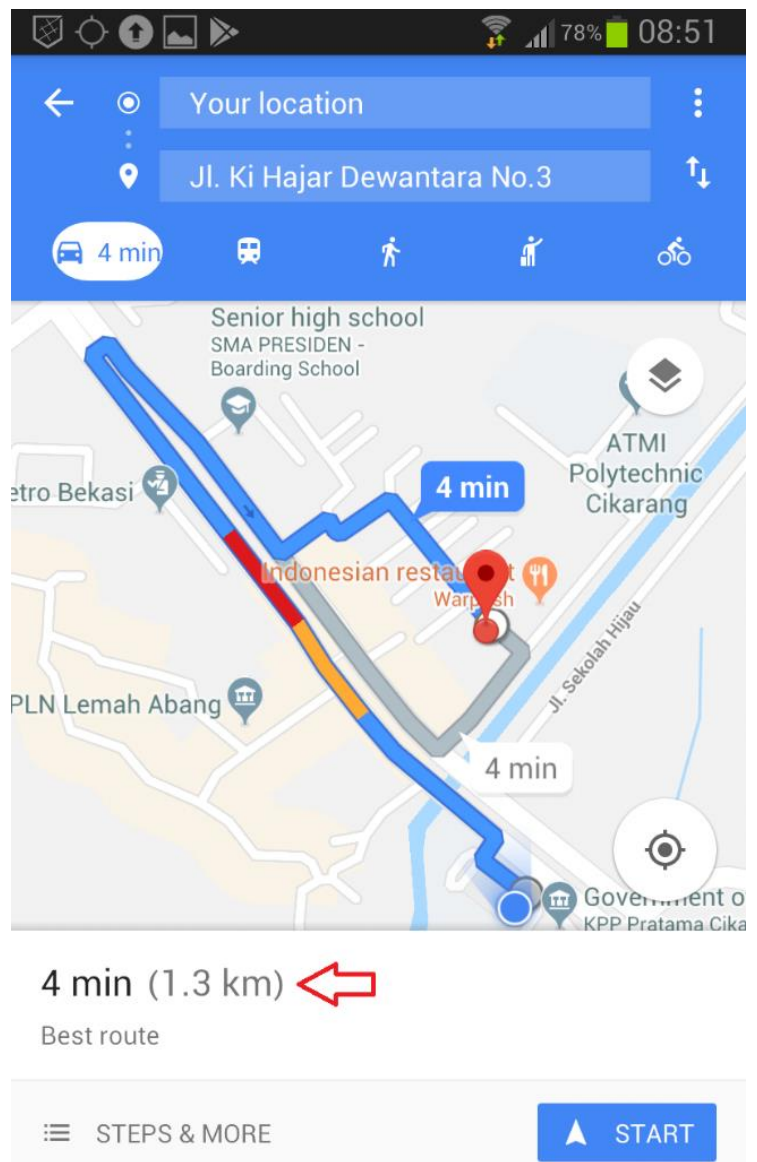

Gambar 8

Informasi mengenai Rute, Waktu dan Jarak yang Harus Ditempuh

Setelah mendapatkan informasi yang cukup, penyedia jasa bisa memberikan biaya untuk penawaran tersebut. Caranya dengan mengetikkan nilai tersebut pada kotak '-ketikan penawaran-' seperti yang ditunjukkan oleh angka 2 dalam Gambar 7. Setelah nilai yang diinginkan selesai diketik, selanjutnya diteruskan dengan menyentuh tombol 'Tawarkan' (angka 3) untuk mengirimkan data ke dalam sistem. Sistem akan melakukan verifikasi dan jika semua sudah benar maka sistem akan meneruskan penawaran tersebut kepada pengguna jasa. Contoh penawaran yang sudah siap untuk dikirim ke dalam sistem ditunjukkan oleh Gambar 9. Biaya yang diinginkan telah diketikkan yaitu ‘5000' seperti yang ditunjukkan oleh panah merah.

Gambar 10 menunjukkan daftar biaya yang ditawarkan oleh penyedia jasa terhadap sebuah kebutuhan. Dari halaman ini seorang pengguna jasa dapat memilih sendiri layanan mana yang akan disetujui. Pilihan dilakukan dengan menyentuh tombol yang bersesuaian seperti yang ditunjukkan dalam gambar angka 1 merah untuk tawaran dari 'dlvry003' dan angka 2 hitam untuk tawaran dari 'dlvry004'. 
Academics in Action Journal

Volume 1, Number 1, 2019, 38-49

\section{D.L.V.R.Y.}

\section{ambil fotocopi di ABC} dlvry001 (4.8/5)

0818123456

\section{Lihat peta..}

\section{Tawarkan}

Gambar 9

Contoh Penawaran Biaya Kirim

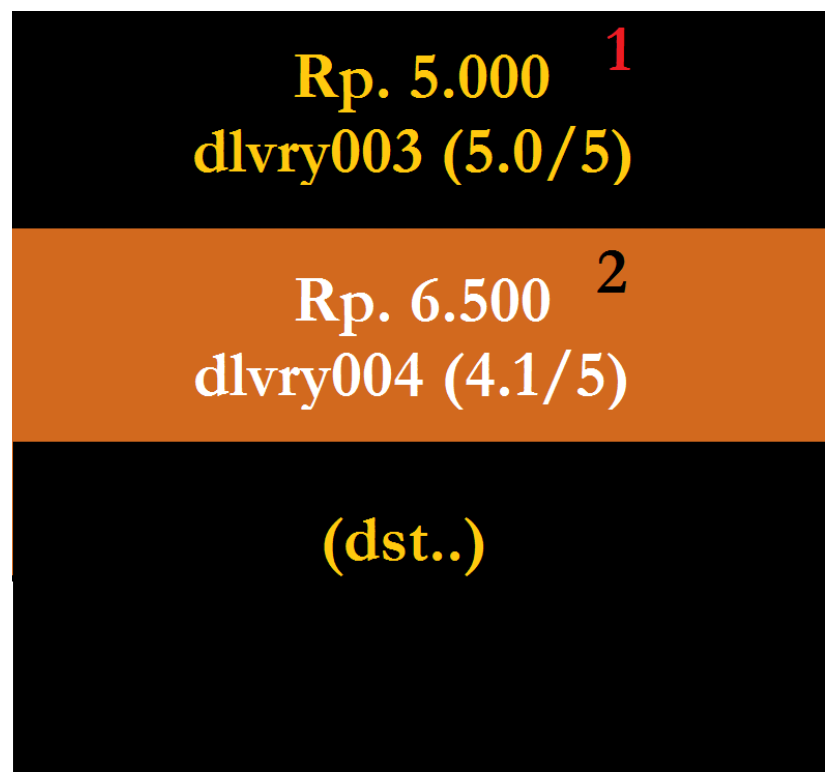

Gambar 10

Tampilan Daftar Biaya yang Ditawarkan 


\section{KESIMPULAN}

Kegiatan pengabdian kepada masyarakat mengenai pengembangan aplikasi mobile untuk mendukung Usaha Jasa Pengantaran Barang di Dusun Cibeber telah dilakukan. Aplikasi yang dikembangkan telah diujicoba dan disimulasikan fitur-fiturnya dan berjalan dengan baik. Aplikasi memiliki dua mode penggunaan yaitu sebagai pengguna jasa dan sebagai penyedia jasa. Hal tersebut dikemas dalam satu aplikasi sehingga sangat baik dari sudut pandang fleksibilitas. Selain itu sisi server juga sebagai sistem pendukung telah berhasil dikembangkan dan dapat sepenuhnya mendukung kebutuhan aplikasi dari awal sampai akhir secara keseluruhan.

Kegiatan pengabdian selanjutnya yang terkait dengan topik ini adalah dengan melakukan uji coba lapangan yang disertai dengan pelatihan kepada calon pengguna. Hal ini ditujukan untuk dapat mencapai tujuan utama yaitu mengatasi masalah banyaknya warga yang tidak memiliki pekerjaan di Dusun Cibeber melalui pembukaan sumber pendapatan baru yang sederhana dan tidak membutuhkan kualifikasi sumber daya manusia yang tinggi. Aplikasi ini sangat membantu banyak pihak dan cukup menjanjikan sebagai bentuk wirausaha baru yang memanfaatkan teknologi. Dari sisi aplikasi dan sistem, penerapan langsung di lingkungan nyata dapat memberikan umpan balik yang sangat berguna. Hal ini tentunya sangat baik untuk perbaikan berkelanjutan.

\section{UCAPAN TERIMA KASIH}

Kegiatan PKM ini memperoleh sumberdana dari Lembaga Riset dan Pengabdian Masyarakat Universitas Presiden. Terima kasih yang sebesar-besarnya kami ucapkan untuk semua pihak yang terlibat dalam pendanaan, pelaksanaan, dan mitra dalam kegiatan PKM ini.

\section{REFERENSI}

Beck, K. (2000). Extreme Programming Explained: Embrace Change. IEEE Magazine.

Charland, A. \& Leroux, B. (2011). Mobile Application Development: Web vs. Native. Communicatoons of the ACM, 54(5), 49-53.

Google Map (https://cloud.google.com/maps-platform/) . Diunduh pada 20 Maret 2019.

Maina, T. (2013). Instant Messaging an Effective Way of Communication in Workplace. arXiv.

Upadhyaya, S.D., Pettygrove, S., Oliveira, W. J., Jahn, R.B. (2019). An Introduction-Global Positioning System. 